The Chittagong Univ. J. B. Sci., Vol. 6(1 \&2):159-173, 2011.

\title{
ISOLATION, IDENTIFICATION AND CHARACTERIZATION OF FOUR CELLULOLYTIC ACTINOMYCETES AND THEIR CELLULASES
}

\author{
M. Z. ALAM $^{1}$, M. SULTANA ${ }^{1}$ AND M. N. ANWAR ${ }^{1 *}$ \\ Department of Microbiology, University of Chittagong, Chittagong-4331, Bangladesh.
}

\begin{abstract}
Four highly cellulolytic actinomycetous isolates namely $\mathrm{SG}_{1}, \mathrm{SG}_{2}, \mathrm{SG}_{3}$ and $\mathrm{SS}_{1}$ were isolated from soil samples and provisionally identified as Streptomyces almquistii, S. caeruleus, S. hirsutus and S. endus, respectively. All the isolates showed heavy growth and liquefaction at $50^{\circ} \mathrm{C}$ and $\mathrm{pH} 6.5$ in Winstead's medium having $1.2 \%$ of CMC. The isolates were allowed to grow in Winstead's medium having Asparagine as a nitrogen source with different carbon sources for the maximum production of cellulases. The extracellular protein of the culture supernatant ranged from $1.14 \mu \mathrm{g} / \mathrm{ml}\left(\mathrm{SG}_{1}\right)$ to $879.39 \mu \mathrm{g} / \mathrm{ml}\left(\mathrm{SG}_{3}\right)$. The reducing

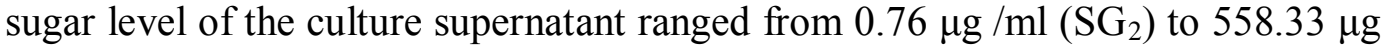
$/ \mathrm{ml}\left(\mathrm{SG}_{1}\right)$. The highest CMC-ase activity $(1431.81 \mathrm{U} / \mathrm{ml})$ was found with the crude enzyme of the strain $\mathrm{SG}_{3}$. The highest FP-ase activity $(1087.11 \mathrm{U} / \mathrm{ml})$ and Avicelase activity $(1287.87 \mathrm{U} / \mathrm{ml})$ were found with the crude enzyme of $\mathrm{SS}_{1}$. To detrermine the optimum nitrogen sources, the isolates were allowed to grow in Winstead's medium having saw dust for $\mathrm{SG}_{1}$ and $\mathrm{SG}_{3}$, dry leaf for $\mathrm{SS}_{1}$ and $\mathrm{SG}_{2}$ as a carbon source with different nitrogen sources for the maximum production of cellulases. The extracellular protein of the culture supernatant ranged from 35.50 $\mu \mathrm{g} / \mathrm{ml}\left(\mathrm{SG}_{1}\right)$ to $328.62 \mu \mathrm{g} / \mathrm{ml}\left(\mathrm{SS}_{1}\right)$ and the reducing sugar level of the culture

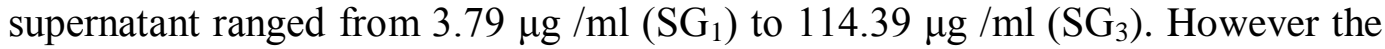
highest CMC-ase activity $(1353.78 \mathrm{U} / \mathrm{ml})$, and FP-ase activity $(215.90 \mathrm{U} / \mathrm{ml})$ were found with the crude enzyme of the strain $\mathrm{SG}_{2}$ and Avicelase activity $(356.06 \mathrm{U} / \mathrm{ml})$ was found with the crude enzyme of the isolate $\mathrm{SS}_{1}$.
\end{abstract}

Key words: Streptomyces, Winstead's

\section{INTRODUCTION}

Cellulose is a long-chain polysaccharide of $\beta$-glucose and the most abundant organic compound on earth. The primary cell wall of green plants is made primarily of cellulose and the secondary wall contains cellulose with variable amounts of lignin. Lignin and cellulose, considered together, are termed

${ }^{*}$ Corresponding author: anwarmn51@yahoo.com 
lignocellulose, which is the most common biopolymer on Earth. While humans cannot digest cellulose, many even-toed ungulates and termites can digest cellulose through a mutually beneficial symbiotic relationship with particular microorganisms that can break down the cellulose to usable form (Updegraff 1969, Crawford 1981, Ozturk et al. 2006,). Cellulolysis is the process of breaking down cellulose into smaller polysaccharides called cellodextrins or completely into glucose units which is a hydrolysis reaction. Because cellulose molecules bind strongly to each other, cellulolysis is relatively a difficult process compared to the break down of other polysaccharides (David et al. 2008)

Most mammals have only very limited ability to digest cellulose. Some ruminants like cows and sheep contain certain symbiotic anaerobic bacteria (like Cellulomonas) in the flora of the rumen which produce enzymes called cellulases that help the microorganism to break down cellulose and the breakdown products are then used by the bacteria for proliferation. The bacterial mass is later digested by the ruminant in its digestive system like stomach and small intestine (Tokuda and Watanabe 2007). Although cellulases are distributed throughout the biosphere, they are mostly found in fungi and other microbial sources. The actinomycetes are an important part of the microbial community in the soil environment, responsible for degradation and recycling of natural biopolymers, such as cellulose, lignin and chitin (Semedo et al. 2001) and also a source of a wide range of other types of bioactive compounds for biotechnological applications (Okami and Hotta 1988, Bull et al. 1992).

In this study, we describe the isolation and characterization of 4 cellulolytic actinomycetes to find out the optimum conditions for growth and enzymatic activities of the isolates.

\section{MATERIALS AND METHODS}

\section{Substrate Preparation}

Saw dust, rice bran, sugarcane baggage, coconut husk, dry leaf and CMC were used as substrates. The natural cellulosic substrates were pretreated by boiling in $0.5 \% \mathrm{NaOH}$ for 1 hour following the Gray method (Gray et al.1978)

\section{Microorganisms}

Four Streptomyces species $\left(\mathrm{SG}_{1}, \mathrm{SG}_{2}, \mathrm{SG}_{3}\right.$ and $\left.\mathrm{SS}_{1}\right)$ were isolated from soil. After isolation the organisms were purified through repeated plating in Nutrient Agar medium. On the basis of morphological and cultural characteristics 
ISOLATION, IDENTIFICATION AND CHARACTERIZATION OF FOUR CELLULOLYTIC ACTINOMYCETES AND THEIR CELLULASES

the isolates $\mathrm{SG}_{1}, \mathrm{SG}_{2}, \mathrm{SG}_{3}$ and $\mathrm{SS}_{1}$ were provisionally identified as Streptomyces almquistii (Duche 1934) Streptomyces caeruleus(Baldacci 1944). Streptomyces hirsutus (Ettlinger et.al.1958) and Streptomyces endus (Anderson and Gottlieb 1952) respectively.

\section{Biomass yield}

The filter paper containing biomass residue was dried in oven at $80^{\circ} \mathrm{C}$ for a constant weight and the amount of biomass was calculated.

\section{Optimization of cultural conditions}

An attempt was also made to determine the optimum culture conditions such as $\mathrm{pH}$, temperature, carbon and nitrogen source requirements for their maximum growth and activities. The biomass yield, extracellular protein, reducing sugar level and cellulase production of the isolates was recorded.

\section{Medium $\mathrm{pH}$}

To observe the effect of medium $\mathrm{pH}$ on enzyme production, selected medium $\mathrm{pH}$ of $4.5,6.5,7.0,7.5$ and 8.5 was inoculated with the isolates. The effects of medium $\mathrm{pH}$ on growth and liquefaction were recorded.

\section{Temperature}

To determine the optimum temperature for enzyme production the culture medium was incubated at $10^{\circ}, 27^{\circ}, 37^{\circ}, 45^{\circ}, 50^{\circ}$ and $55^{\circ} \mathrm{C}$ temperature at optimum $\mathrm{pH}$ and incubation period. The effects of temperature on growth and liquefaction were recorded.

\section{Carbon and nitrogen sources}

The production of cellulase under different carbon and nitrogen sources were studied in the liquid culture medium. Six carbon (CMC, Saw dust, Rice bran, Sugarcane baggage, Dry leaf and Coconut husk) and five nitrogen (Asparagine, Urea, Beef extract, Yeast extract and Peptone) sources were added to the medium and the effect of this carbon and nitrogen sources on the production of cellulase, extracellular protein, reducing sugar level and biomass yield were recorded.

Enzyme assay

For CMC-ase activity $2 \mathrm{ml}$ of filtrate was added to $2 \mathrm{ml}$ of $1 \% \mathrm{CMC}$ and

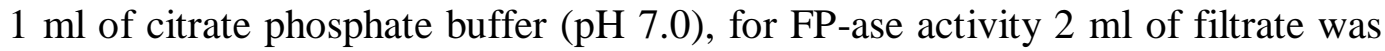


added to $1 \mathrm{ml}$ of citrate phosphate buffer along with $50 \mathrm{mg}$ Whatman No-1 filter paper strip (1x6 cm) and for Avicilase activity $2 \mathrm{ml}$ of filtrate was added to $2 \mathrm{ml}$ of $1 \%$ Avicel and $1 \mathrm{ml}$ of citrate phosphate buffer in a test tube and incubated at $37^{\circ} \mathrm{C}$ for 2 hours in a water bath. The amount of reducing sugars released in CMC-ase, FP-ase and Avicilase assay after incubation was measured by Nelson's modification of Somogyi method (Somogyi 1944). Enzyme activity was expressed by the amount of glucose released in $\mu \mathrm{g} / \mathrm{ml}$ of crude enzyme/ hour enzyme-substrate reaction at given conditions (Mahadevan and Sridhar 1982). Soluble protein in cultrate filtrate was estimated following the Lowry method (Lowry et al. 1951).

\section{Saccharification}

Saccharification (\%) was calculated by applying the following equation:

$$
\text { Saccharification } \%=\frac{\mathrm{mg} \text {. of reducing sugar per } \mathrm{ml}}{\mathrm{mg} \text {. of substrate per } \mathrm{ml}} \quad \times 100
$$

\section{RESULTS AND DISCUSSION}

\section{Effects of Medium $\mathrm{pH}$ and Temperature}

At low pH (4.5), all the isolates showed low growth and liquefaction in Winstead's medium having $1.2 \%$ of CMC. At $\mathrm{pH} 8.5$ all the isolates showed moderate growth and liquefaction except $\mathrm{SG}_{3}$, which showed heavy growth at $\mathrm{pH}$ 8.5. All the isolates showed heavy growth and liquefaction at $\mathrm{pH} 6.5$. At $50^{\circ} \mathrm{C}$ all the isolates showed heavy growth and liquefaction. The isolates $\mathrm{SG}_{2}$ and $\mathrm{SG}_{3}$ also showed heavy growth and liquefaction at $45^{\circ} \mathrm{C}$. But at $10^{\circ} \mathrm{C}$, all the isolates were found to be unable to degrade the cellulose (CMC). (Table 1)

Heavy growth at $\mathrm{pH} 6.5$ to 7.5 with different microorganisms was reported by many workers (Malek et al .1987, Shailendra et al.1991, Hossain et al.1999, Farhana et al. 2000). Heavy growth of actinomycetes at temperature $50^{\circ} \mathrm{C}$ was reported by many workers (Cresswell et al. 1988, Jang and Chen 2003).The present observation is in concurrence with their reports.

Both $\mathrm{pH}$ and temperature have an effect on cellulose liquefaction. The higher liquefaction of cellulose due to enzyme activity at $\mathrm{pH} 6.5$ to 7.5 was reported by many workers ( Malek et al.1987, Araujo and Ward 1990, Hachiro 
ISOLATION, IDENTIFICATION AND CHARACTERIZATION OF FOUR CELLULOLYTIC ACTINOMYCETES AND THEIR CELLULASES

and Kazuhiko 1991, Shailendra et al. 1991, Hossain et al. 1998, Hossain et al.1999).The higher liquefaction of cellulose due to enzyme activity at $50^{\circ} \mathrm{C}$ was reported by Kaneko et al. 2005 and Lee et al. 2006. This observation also showed similarities with their reports.

TABLE 1: EFFECT OF pH AND TEMPERATURE ON THE GROWTH AND LIQUEFACTION OF THE SELECTED ISOLATES.

\begin{tabular}{cccccc|ccccccc}
\hline Isolate & \multicolumn{5}{c|}{$\mathrm{pH}$} & \multicolumn{5}{c}{ Temperature $\left({ }^{\circ} \mathrm{C}\right)$} \\
\cline { 2 - 11 } $\mathrm{Nos}$ & 8.5 & 7.5 & 7.0 & 6.5 & 4.5 & 10 & 27 & 37 & 45 & 50 & 55 \\
\hline $\mathrm{SG}_{1}$ & ++ & ++ & ++ & +++ & + & - & + & + & ++ & +++ & ++ \\
$\mathrm{SG}_{2}$ & ++ & ++ & ++ & +++ & + & - & + & + & +++ & +++ & ++ \\
$\mathrm{SG}_{3}$ & +++ & ++ & ++ & +++ & + & - & + & ++ & +++ & +++ & ++ \\
$\mathrm{SS}_{1}$ & ++ & ++ & ++ & +++ & + & - & + & ++ & ++ & +++ & ++ \\
\hline \multicolumn{7}{c}{} \\
\hline
\end{tabular}

\section{Effects of Carbon sources}

The isolates were allowed to grow in Winstead's medium having Asparagine as a nitrogen source and 1.2\% of CMC / Saw dust/ Rice bran/ Sugarcane baggage/ Coccunut husk/ Dry leaf as a carbon source for the determination of optimum carbon sources for maximum production of cellulase, reducing sugar level, extracellular protein, saccharificaton $(\%)$ and biomass (Table 2). The change of $\mathrm{pH}$ of the culture supernatant ranged from 7.5 to 8.4.

The extracellular protein of culture supernatant of the isolates $\mathrm{SG}_{1}, \mathrm{SS}_{1}$, $\mathrm{SG}_{2}$ and $\mathrm{SG}_{3}$ ranged from $1.14 \mu \mathrm{g} / \mathrm{ml}$ (sugarcane baggage) to $588.55 \mu \mathrm{g} / \mathrm{ml}$ (coccunut husk), $17.17 \mu \mathrm{g} / \mathrm{ml}$ (dry leaf) to $677.86 \mu \mathrm{g} / \mathrm{ml}$ (CMC), $53.82 \mu \mathrm{g} / \mathrm{ml}$ (Saw dust) to $480.92 \mu \mathrm{g} / \mathrm{ml}$ ( Rice Bran) and $9.16 \mu \mathrm{g} / \mathrm{ml}$ (Dry leaf) to $879.39 \mu \mathrm{g}$ $/ \mathrm{ml}(\mathrm{CMC})$ respectively. and Reducing sugar level of the isolates $\mathrm{SG}_{1}, \mathrm{SS}_{1}, \mathrm{SG}_{2}$ and $\mathrm{SG}_{3}$ ranged from $7.57 \mu \mathrm{g} / \mathrm{ml}$ (coconut husk) to $558.33 \mu \mathrm{g} / \mathrm{ml}$ (saw dust), $18.94 \mu \mathrm{g} / \mathrm{ml}$ (saw dust) to $302.27 \mu \mathrm{g} / \mathrm{ml}$ (sugarcane baggage), $0.757 \mu \mathrm{g} / \mathrm{ml}$ (Sugarcane baggage) to $459.09 \mu \mathrm{g} / \mathrm{ml}$ (Dry leaf) and $4.54 \mu \mathrm{g} / \mathrm{ml}$ (Sugarcane baggage) to $365.91 \mu \mathrm{g} / \mathrm{ml}$ (Saw dust) respectively. 
Highest saccharification percentage for the isolates $\mathrm{SG}_{1}, \mathrm{SS}_{1}, \mathrm{SG}_{2}$ and $\mathrm{SG}_{3}$ were found $4.65 \%$ (saw dust), 2.52\% (sugarcane baggage), 3.82\% (Dry leaf) and $3.05 \%$ (Saw dust) and highest biomass yield were found $411.67 \mathrm{mg} / \mathrm{gm}$ (rice bran), $348.33 \mathrm{mg} / \mathrm{gm}$ (sugarcane baggage), $266.67 \mathrm{mg} / \mathrm{gm}$ (Coconut husk) and $281.67 \mathrm{mg} / \mathrm{gm}$ (Dry leaf) respectively.

\section{Effect of Nitrogen sources}

The isolates were then allowed to grow in Winstead's medium having saw dust for $\mathrm{SG}_{1}$ and $\mathrm{SG}_{3}$ and dry leaf for $\mathrm{SS}_{1}$ and $\mathrm{SG}_{2}$ as a carbon source and Asparagine/Urea/Beef extract/Yeast extract/Peptone as a nitrogen source for the determination of optimum nitrogen sources for maximum production of cellulase, reducing sugar level, extracellular protein, saccharification (\%), biomass (Table 3). The change of $\mathrm{pH}$ of the culture supernatant ranged from 7.7 to 8.6.

Extracellular protein of culture supernatant of the isolates $\mathrm{SG}_{1}, \mathrm{SS}_{1}, \mathrm{SG}_{2}$ and $\mathrm{SG}_{3}$ ranged from $35.50 \mu \mathrm{g} / \mathrm{ml}$ (Asparagine) to $262.21 \mu \mathrm{g} / \mathrm{ml}$ (Beef extract), $92.75 \mu \mathrm{g} / \mathrm{ml}$ (Beef extract) to $328.62 \mu \mathrm{g} / \mathrm{ml}$ (Urea), $49.24 \mu \mathrm{g} / \mathrm{ml}$ (Urea) to $211.83 \mu \mathrm{g} / \mathrm{ml}$ (Peptone) and $92.75 \mu \mathrm{g} / \mathrm{ml}$ (Asparagine) to $248.47 \mu \mathrm{g} / \mathrm{ml}$ (Peptone) respectively. Reducing sugar level of the isolates $\mathrm{SG}_{1}, \mathrm{SS}_{1}, \mathrm{SG}_{2}$ and $\mathrm{SG}_{3}$ ranged from $3.79 \mu \mathrm{g} / \mathrm{ml}$ ( Peptone) to $56.81 \mu \mathrm{g} / \mathrm{ml}($ Urea), $18.18 \mu \mathrm{g} / \mathrm{ml}$ (Peptone) to $70.45 \mu \mathrm{g} / \mathrm{ml}$ (Asparagine), $5.30 \mu \mathrm{g} / \mathrm{ml}$ ( Peptone) to $28.03 \mu \mathrm{g}$ $/ \mathrm{ml}$ (Beef extract) and $7.57 \mu \mathrm{g} / \mathrm{ml}$ (Peptone) to $114.39 \mu \mathrm{g} / \mathrm{ml}$ (Urea) respectively.

Highest saccharification percentage of the isolates $\mathrm{SG}_{1}, \mathrm{SS}_{1}, \mathrm{SG}_{2}$ and $\mathrm{SG}_{3}$ were found $0.47 \%$ (Urea), $0.58 \%$ (Asparagine), $0.23 \%$ (Beef extract) and $0.95 \%$ (Urea) and highest biomass yield were found $236.67 \mathrm{mg} / \mathrm{gm}$ (Peptone), 331.67 $\mathrm{mg} / \mathrm{gm}$ (Peptone), $351.67 \mathrm{mg} / \mathrm{gm}$ (Asparagine) and $228.33 \mathrm{mg} / \mathrm{gm}$ (Peptone) respectively. 
ISOLATION, IDENTIFICATION AND CHARACTERIZATION OF FOUR CELLULOLYTIC ACTINOMYCETES AND THEIR CELLULASES

TABLE 2: EXTRACELLULAR PROTEIN, REDUCING SUGAR LEVEL, BIOMASS YIELD AND SACCHARIFICATION (\%) OF THE SELECTED ISOLATES ON DIFFERENT CARBON SOURCES.

\begin{tabular}{|c|c|c|c|c|c|c|}
\hline $\begin{array}{c}\text { Sources } \\
\text { of } \\
\text { carbon }\end{array}$ & $\begin{array}{c}\text { Isolate } \\
\text { Nos }\end{array}$ & $\begin{array}{c}\text { Final } \\
\mathrm{pH}\end{array}$ & $\begin{array}{l}\text { Extra- } \\
\text { cellular } \\
\text { protein } \\
\mu \mathrm{g} / \mathrm{ml}\end{array}$ & $\begin{array}{c}\text { Reducing } \\
\text { sugar } \\
\mu \mathrm{g} / \mathrm{ml}\end{array}$ & $\begin{array}{l}\text { Biomass } \\
\text { yield } \\
\mathrm{mg} / \mathrm{ml} \\
\text { cellulose }\end{array}$ & $\begin{array}{l}\text { Sacchari- } \\
\text { fication } \\
(\%)\end{array}$ \\
\hline \multirow{4}{*}{$\mathrm{CMC}$} & $\mathrm{SG}_{1}$ & 8.2 & 429.39 & 412.87 & 258.33 & 3.44 \\
\hline & $\mathrm{SS}_{1}$ & 8.3 & 677.86 & 81.82 & 213.67 & 0.68 \\
\hline & $\mathrm{SG}_{3}$ & 8.3 & 879.39 & 92.42 & 256.67 & 0.77 \\
\hline & $\mathrm{SG}_{2}$ & 8.3 & 61.83 & 22.73 & 218.33 & 0.19 \\
\hline \multirow[t]{4}{*}{ Saw dust } & $\mathrm{SG}_{1}$ & 7.7 & 580.53 & 558.33 & 195.00 & 4.65 \\
\hline & $\mathrm{SS}_{1}$ & 7.5 & 396.18 & 18.94 & 161.67 & 0.16 \\
\hline & $\mathrm{SG}_{3}$ & 7.6 & 113.36 & 365.91 & 241.67 & 3.05 \\
\hline & $\mathrm{SG}_{2}$ & 7.7 & 53.82 & 31.82 & 205.00 & 0.27 \\
\hline \multirow[t]{4}{*}{ Rice bran } & $\mathrm{SG}_{1}$ & 7.7 & 9.16 & 550.33 & 411.67 & 4.60 \\
\hline & $\mathrm{SS}_{1}$ & 8.2 & 177.48 & 18.98 & 335.00 & 0.16 \\
\hline & $\mathrm{SG}_{3}$ & 8.0 & 652.67 & 360.91 & 243.33 & 3.05 \\
\hline & $\mathrm{SG}_{2}$ & 8.2 & 480.92 & 31.82 & 200.00 & 0.27 \\
\hline \multirow{4}{*}{$\begin{array}{c}\text { Sugarcane } \\
\text { baggage }\end{array}$} & $\mathrm{SG}_{1}$ & 7.5 & 1.14 & 389.39 & 173.33 & 3.24 \\
\hline & $\mathrm{SS}_{1}$ & 8.2 & 96.47 & 302.27 & 348.33 & 2.52 \\
\hline & $\mathrm{SG}_{3}$ & 8.2 & 81.30 & 4.54 & 246.67 & 0.03 \\
\hline & $\mathrm{SG}_{2}$ & 8.1 & 75.57 & 0.76 & 240.00 & 0.01 \\
\hline \multirow{4}{*}{ Dry leaf } & $\mathrm{SG}_{1}$ & 8.2 & 19.46 & 11.36 & 178.33 & 0.09 \\
\hline & $\mathrm{SS}_{1}$ & 8.2 & 17.17 & 287.12 & 220.00 & 2.39 \\
\hline & $\mathrm{SG}_{3}$ & 8.1 & 9.16 & 7.57 & 281.67 & 0.06 \\
\hline & $\mathrm{SG}_{2}$ & 8.1 & 444.27 & 459.09 & 236.67 & 3.82 \\
\hline \multirow{4}{*}{$\begin{array}{l}\text { Coconut } \\
\text { husk }\end{array}$} & $\mathrm{SG}_{1}$ & 8.2 & 588.55 & 7.57 & 176.67 & 0.06 \\
\hline & $\mathrm{SS}_{1}$ & 8.1 & 253.05 & 23.48 & 193.33 & 0.19 \\
\hline & $\mathrm{SG}_{3}$ & 8.4 & 502.67 & 159.85 & 215.00 & 1.33 \\
\hline & $\mathrm{SG}_{2}$ & 8.3 & 195.80 & 26.51 & 266.67 & 0.22 \\
\hline
\end{tabular}


ALAM et al.

TABLE 3: EXTRACELLULAR PROTEIN, REDUCING SUGAR LEVEL, BIOMASS YIELD AND SACCHARIFICATION (\%) OF THE SELECTED ISOLATES ON DIFFERENT NITROGEN SOURCES.

\begin{tabular}{|c|c|c|c|c|c|c|}
\hline $\begin{array}{l}\text { Sources } \\
\text { of } \\
\text { Nitrogen }\end{array}$ & $\begin{array}{c}\text { Isolate } \\
\text { Nos }\end{array}$ & $\begin{array}{c}\text { Final } \\
\mathrm{pH}\end{array}$ & $\begin{array}{l}\text { Extra- } \\
\text { cellular } \\
\text { protein } \\
\mu \mathrm{g} / \mathrm{ml}\end{array}$ & $\begin{array}{c}\text { Reducing } \\
\text { sugar } \\
\mu \mathrm{g} / \mathrm{ml}\end{array}$ & $\begin{array}{c}\text { Biomass } \\
\text { yield } \\
\text { mg/ml } \\
\text { cellulose }\end{array}$ & $\begin{array}{c}\text { Sacchari- } \\
\text { fication } \\
(\%)\end{array}$ \\
\hline \multirow[t]{4}{*}{ Asparagine } & $\mathrm{SG}_{1}$ & 8.5 & 35.50 & 53.79 & 135.00 & 0.45 \\
\hline & $\mathrm{SS}_{1}$ & 8.4 & 123.66 & 70.45 & 166.67 & 0.58 \\
\hline & $\mathrm{SG}_{3}$ & 8.6 & 92.75 & 73.48 & 181.67 & 0.61 \\
\hline & $\mathrm{SG}_{2}$ & 8.4 & 84.73 & 24.24 & 351.67 & 0.20 \\
\hline \multirow{4}{*}{ Urea } & $\mathrm{SG}_{1}$ & 8.4 & 91.60 & 56.81 & 171.67 & 0.47 \\
\hline & $\mathrm{SS}_{1}$ & 8.5 & 328.62 & 65.91 & 236.67 & 0.55 \\
\hline & $\mathrm{SG}_{3}$ & 7.9 & 217.56 & 114.39 & 191.67 & 0.95 \\
\hline & $\mathrm{SG}_{2}$ & 8.5 & 49.24 & 6.82 & 221.67 & 0.06 \\
\hline \multirow{4}{*}{ Beef extract } & $\mathrm{SG}_{1}$ & 8.1 & 262.21 & 18.94 & 221.67 & 0.16 \\
\hline & $\mathrm{SS}_{1}$ & 7.7 & 92.75 & 34.09 & 316.67 & 0.28 \\
\hline & $\mathrm{SG}_{3}$ & 8.2 & 247.33 & 54.54 & 191.67 & 0.45 \\
\hline & $\mathrm{SG}_{2}$ & 8.3 & 156.87 & 28.03 & 133.33 & 0.23 \\
\hline \multirow{4}{*}{$\begin{array}{l}\text { Yeast } \\
\text { extract }\end{array}$} & $\mathrm{SG}_{1}$ & 8.2 & 178.63 & 54.54 & 200.00 & 0.45 \\
\hline & $\mathrm{SS}_{1}$ & 8.5 & 201.53 & 41.67 & 311.67 & 0.35 \\
\hline & $\mathrm{SG}_{3}$ & 8.2 & 178.63 & 12.12 & 151.67 & 0.10 \\
\hline & $\mathrm{SG}_{2}$ & 8.2 & 85.88 & 12.12 & 338.33 & 0.10 \\
\hline \multirow[t]{4}{*}{ Peptone } & $\mathrm{SG}_{1}$ & 8.2 & 192.37 & 3.79 & 236.67 & 0.03 \\
\hline & $\mathrm{SS}_{1}$ & 8.3 & 199.24 & 18.18 & 331.67 & 0.15 \\
\hline & $\mathrm{SG}_{3}$ & 8.1 & 248.47 & 7.57 & 228.33 & 0.06 \\
\hline & $\mathrm{SG}_{2}$ & 8.0 & 211.83 & 5.30 & 333.33 & 0.04 \\
\hline
\end{tabular}

Enzyme activity

The quantitative cellulase activity (CMC-ase, FP-ase \& Avicelase) of crude enzymes produced by the isolates $\mathrm{SG}_{1}, \mathrm{SS}_{1}, \mathrm{SG}_{2}$ and $\mathrm{SG}_{3}$ grown in liquid Winstead's medium having 1.2\% of CMC / saw dust/ rice bran/ sugarcane baggage/ coconut husk/ dry leaf (as a carbon source) were shown in Table 4. 
ISOLATION, IDENTIFICATION AND CHARACTERIZATION OF FOUR CELLULOLYTIC ACTINOMYCETES AND THEIR CELLULASES

Among the four isolates, the isolate $\mathrm{SG}_{3}$ showed highest $\mathrm{CMC}$-ase activity $1431.81 \mathrm{U} / \mathrm{ml}$ and $\mathrm{SG}_{2}$ showed the lowest $\mathrm{CMC}$-ase activity1.51 U/ml. The isolate $\mathrm{SS}_{1}$ showed highest FP-ase activity $1087.11 \mathrm{U} / \mathrm{ml}$ and the lowest FP-ase activity $0.77 \mathrm{U} / \mathrm{ml}$ was recorded with crude enzyme of the strain $\mathrm{SG}_{1}$.

The highest and lowest Avicelase activity was found $1287.87 \mathrm{U} / \mathrm{ml}$ and $1.89 \mathrm{U} / \mathrm{ml}$ with the isolate $\mathrm{SS}_{1}$ respectively.

Induction or repression of microbial cellulase enzyme production due to addition of different carbon sources to the cellulose medium was reported by many workers (Mandel and Reese 1957, Mandel et al.1962, Martin and Eberhart 1966, Mandel and Weber 1969, Nisizawa et al.1972. Breuli and Krushner 1976, Donald et al. 1995, Kashem 1998, Hossain et al.1999, Huq et al. 2002, Alam et al. 2004).The present observations are in concurrence with many of the above reports.

The quantitative cellulase activity (CMC-ase, FP-ase \& Avicelase) of crude enzymes produced by the selected isolates while grown in liquid Winstead's medium having saw dust for $\mathrm{SG}_{1}$ and $\mathrm{SG}_{3}$, dry leaf for $\mathrm{SS}_{1}$ and $\mathrm{SG}_{2}$ as a carbon source and Asparagine/ Urea/ Beef extract/ Yeast extract / Peptone as a nitrogen source are shown in the Table 5. The highest CMC-ase activity was $1353.78 \mathrm{U} / \mathrm{ml}$ and lowest was $7.57 \mathrm{U} / \mathrm{ml}$ with the crude enzyme of the isolate $\mathrm{SG}_{2}$ was recorded .

The highest FP-ase activity $215.90 \mathrm{U} / \mathrm{ml}$ was recorded with the isolate $\mathrm{SG}_{2}$ and lowest FP-ase activity $9.09 \mathrm{U} / \mathrm{ml}$ with the crude enzyme of the strain $\mathrm{SG}_{1}$.The highest Avicelase activity $356.06 \mathrm{U} / \mathrm{ml}$ was observed with $\mathrm{SS}_{1}$ and lowest Avicelase activity $11.36 \mathrm{U} / \mathrm{ml}$ was recorded with $\mathrm{SG}_{3}$.

The induction or repression of microbial cellulase enzymes production due to addition of different nitrogen sources in the medium reported by some earlier workers (Shewale and Sadana 1968, Kashem 1998, Hossain et al.1999, Huq et al. 2002). In the present study both the induction and repression of cellulase production was recorded with different nitrogen sources.

Comparative study of enzyme production by the four actinomycetes indicated that CMC-ase activity was found higher compared to that of FP-ase and Avicelase activity, which is in accordance with the findings of many workers (Grag and Neelkanten 1982, Reddy 1984, Anwar and Zaman 1994, Rahman and Anwar 1996, Manchur and Anwar 1998, Shibli et al. 2001, Shibli et al. 2002, Alam et al. 2004, Alam et al. 2006). 
ALAM et al.

The microbial biomass produced by the isolates indicated that the biomass yield and cellulase activity have no direct correlation. Similar observation have also been made by many other workers (Zaman, 1990, Mortuza 1993, Zakir 1994, Rahman and Anwar 1996, Manchur and Anwar 1998, Alam et al. 2004, Alam et al. 2006).

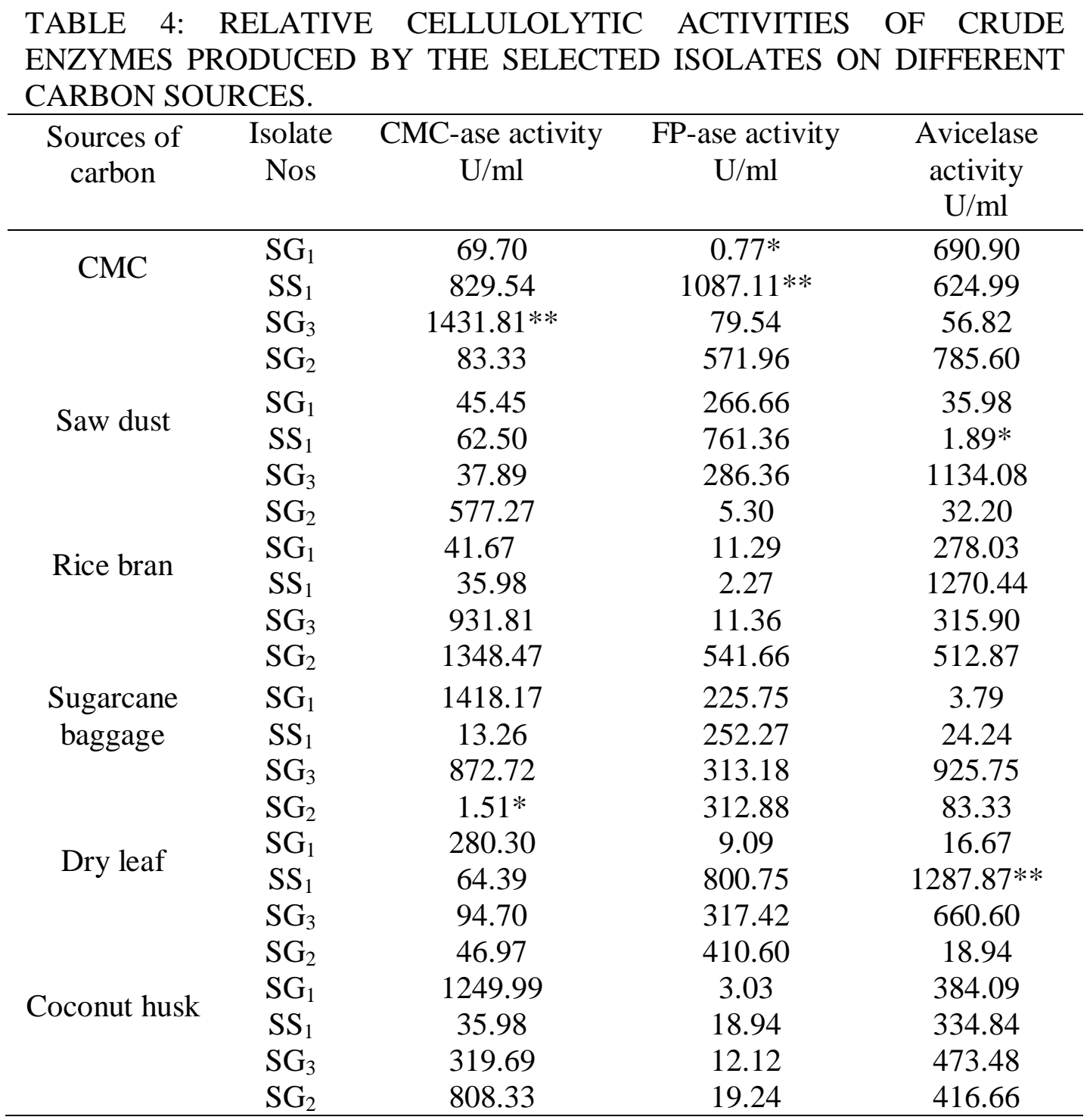

$*$ and $* *$ indicates minimum and maximum respectively 
ISOLATION, IDENTIFICATION AND CHARACTERIZATION OF FOUR CELLULOLYTIC ACTINOMYCETES AND THEIR CELLULASES

TABLE 5: RELATIVE CELLULOLYTIC ACTIVITIES OF CRUDE ENZYMES PRODUCED BY THE SELECTED ISOLATES WITH DIFFERENT NITROGEN SOURCES.

\begin{tabular}{|c|c|c|c|c|}
\hline $\begin{array}{c}\text { Sources of } \\
\mathrm{N}_{2}\end{array}$ & $\begin{array}{c}\text { Isolate } \\
\text { Nos }\end{array}$ & $\begin{array}{c}\text { CMC-ase } \\
\text { activity } \\
\mathrm{U} / \mathrm{ml}\end{array}$ & $\begin{array}{c}\text { FP-ase } \\
\text { activity } \\
\mathrm{U} / \mathrm{ml}\end{array}$ & $\begin{array}{c}\text { Aviceles } \\
\text { activity } \\
\mathrm{U} / \mathrm{ml}\end{array}$ \\
\hline Asparagine & $\begin{array}{l}\mathrm{SG}_{1} \\
\mathrm{SS}_{1} \\
\mathrm{SG}_{3} \\
\mathrm{SG}_{2}\end{array}$ & $\begin{array}{c}232.57 \\
217.40 \\
421.97 \\
1.89\end{array}$ & $\begin{array}{c}85.60 \\
9.09 * \\
124.24 \\
25.76\end{array}$ & $\begin{array}{c}136.36 \\
356.06 * * \\
41.67 \\
45.45\end{array}$ \\
\hline Urea & $\begin{array}{l}\mathrm{SG}_{1} \\
\mathrm{SS}_{1} \\
\mathrm{SG}_{3} \\
\mathrm{SG}_{2}\end{array}$ & $\begin{array}{c}300.75 \\
329.54 \\
53.03 \\
1353.78^{* *}\end{array}$ & $\begin{array}{c}28.03 \\
94.70 \\
195.45 \\
11.36\end{array}$ & $\begin{array}{l}183.33 \\
318.18 \\
11.36^{*} \\
106.06\end{array}$ \\
\hline Beef extrtact & $\begin{array}{l}\mathrm{SG}_{1} \\
\mathrm{SS}_{1} \\
\mathrm{SG}_{3} \\
\mathrm{SG}_{2}\end{array}$ & $\begin{array}{l}175.76 \\
209.85 \\
190.91 \\
651.51\end{array}$ & $\begin{array}{c}22.73 \\
99.24 \\
64.39 \\
215.90^{* * *}\end{array}$ & $\begin{array}{c}75.76 \\
193.18 \\
96.21 \\
66.29\end{array}$ \\
\hline Yeast extract & $\begin{array}{l}\mathrm{SG}_{1} \\
\mathrm{SS}_{1} \\
\mathrm{SG}_{3} \\
\mathrm{SG}_{2}\end{array}$ & $\begin{array}{c}194.69 \\
162.88 \\
31.82 \\
7.57 *\end{array}$ & $\begin{array}{l}34.85 \\
21.21 \\
25.00 \\
25.00\end{array}$ & $\begin{array}{c}68.18 \\
149.24 \\
22.73 \\
28.03\end{array}$ \\
\hline Peptone & $\begin{array}{l}\mathrm{SG}_{1} \\
\mathrm{SS}_{1} \\
\mathrm{SG}_{3} \\
\mathrm{SG}_{2}\end{array}$ & $\begin{array}{c}380.33 \\
189.39 \\
149.24 \\
84.85\end{array}$ & $\begin{array}{c}121.97 \\
40.91 \\
46.21 \\
91.66\end{array}$ & $\begin{array}{c}143.94 \\
299.24 \\
136.36 \\
84.85\end{array}$ \\
\hline
\end{tabular}

$*$ and $* *$ indicate minimum and maximum respectively 
ALAM et al.

\section{REFERENCES}

ALAM, M.Z.. MANCHUR M.A AND ANWAR, M.N. 2004. Isolation, purification, characterization of cellulolytic enzymes produced by the isolate Streptomyces omiyaensis. Pakistan J. Bio. Sci. 7(10): 1647-1653.

ALAM, M.Z., MANCHUR, M.A. AND ANWAR, M.N. 2006. Studies on production of extracellular cellulolytic enzymes by Streptomyces aburaviensis. J. Microb. World 8(1): 76-84.

ANDERSON, H.W. AND GOTTLIEB, D. 1952. In: Bergey's Manual of Determinative Bacteriology (R.E. Buchanan and N.E. Gibbons ed.) 1974. $8^{\text {th }}$ Edn. Williams and Wilkons Co. Baltimore. 1268pp.

ANWAR, M.N. AND ZAMAN, M.Z. 1994. Isolation of cellulolytic microorganisms and screening for cellulose activity. Bangladesh J. Microbiol. 11:49-54.

ARAUJO, A. AND WARD, O.P. 1990. Hemicellulases of Bacillus sp; preliminary comparative studies on production and properties of mannanases and galactanases. J. Appl. Bacteriol. 68: 253-261.

BALDACCI, E. 1944. In: Bergey's Manual of Determinative Bacteriology (R.E. Buchanan and N.E. Gibbons ed.) 1974. $8^{\text {th }}$ Edn. Williams and Wilkons Co. Baltimore. 1268pp.

BREULI, C. AND KRUSHNER, D.J. 1976. Cellulase induction and the use of cellulose as a preferred growth substrate by Celvibrio gilvus. Can. J. Microbiol. 22:1776-1781.

BULL, A.T., GOODFELLOW, M. AND SLATER, J.H. 1992. Biodiversity as a source of innovation in biotechnology. Annu Rev Microbiol 46:219-252.

CRAWFORD, R.L. 1981. Lignin biodegradation and transformation. John Wiley and Sons. New York: ISBN 0471057436.

CRESSWELL, M.A., ATTWELL, R.W. AND DEMPSEY, M.J. 1988 .Detection of cellulolytic actinomycetes using cellulose-azure. Journal of Microbiological Methods. 8(5): 299-302.

DAVID, G., BARKALOW, ROY, L. AND WHISTLER, 2008. "Cellulose", in AccessScience@McGraw-Hill, DOI 10:1036/1097-8542.118200.

DONALD, J.G., GOMES, J. HOQ, M.M. AND STEINER, W. 1995. Induction of cellulose degrading enzymes in Thermoascus aurantiacus. Bangladesh J. Microbiol. 12(1\&2):23-29.

DUCHE, J. 1934. In: Bergey's Manual of Determinative Bacteriology (R.E. Buchanan and N.E. Gibbons ed.) 1974. $8^{\text {th }}$ Edn. Williams and Wilkons Co. Baltimore. 1268pp. 
ISOLATION, IDENTIFICATION AND CHARACTERIZATION OF FOUR CELLULOLYTIC ACTINOMYCETES AND THEIR CELLULASES

ETTLINGER, L.R. CORBAZ AND HUTTER, R. 1958. In: Bergey's Manual of Determinative Bacteriology (R.E. Buchanan and N.E. Gibbons ed.) 1974. $8^{\text {th }}$ Edn. Williams and Wilkons Co. Baltimore. 1268pp.

FARHANA, I.S., CHOWDHURY, N.A., CHOWDHURY, N. AND MALEK, M.A. 2000. Growth and activity of extracellular cellulolytic enzymes of Micromonospora sp. T-24. Bangladesh J. Microbiol. 17(2): 179-186.

GRAG, S.K. AND NEELKANTEN, S. 1982. Effect of mutational factors on cellulose enzymes and microbial protein production by Aspergillus terreus and its evaluation. Biotechnol. Bioeng. 24: 109-125.

GRAY, P.P., HENDY, N.A. AND DUNN, N.W. 1978. Digestion by cellulolytic enzymes of alkali pretreated bagasse. J.Aust. Inst. Agric. Sci. 44: 210-212.

HACHIRO, O. AND KAZUHIKO, Y. 1991. Isolation of Streptomyces sp. producing glucose tolerant glucosidases and properties of the enzymes. Agric. Biol. Chem. 55(4): 779-787.

HOSSAIN, F.M.M., RAHMAN, M.M., CHOWDHURY, N. AND MALEK, M.A. 1998. Extracellular carboxy methyl cellulase and cellobiase of some aerobic bacterial isolates. Bangladesh J. Microbiol. 15(2): 17-26.

HOSSAIN, F.M.M., RAHMAN, M.M., CHOWDHURY, N. AND MALEK, M.A. 1999. Production of extracellular carboxymethyl cellulase and cellobiase by a thermophilic Bacillus sp. Bangladesh J. Microbiol. 16(2): 115-125.

HUQ, M., RAHMAN, M.M., KHAN, A.R. AND MALEK, M.A. 2002. Production of extracellular carboxymethyl cellulose and avicelase by a sawdust degrading Streptomyces sp. Bangladesh J. Microbiol. 19:1-6.

JANG, H.D. AND CHEN, K.S. 2003. Production and characterization of thermostable cellulases from Streptomyces sp. T3-1.World J. Microbiol. Biotechnol. 19: 263-268.

KANEKO, T., OHNO, T. AND OHISA, N. 2005. Purification and characterization of a thermostable raw starch digesting amylase from a Streptomyces sp. isolated in a milling factory. Biotechnol. Biochem. 69(6):1073-1081.

KASHEM, M.A. 1998. Effect of carbon and nitrogen sources on microbial cellulase, saccharification, protein and biomass production. M. Sc. Thesis. Department of Botany, Chittagong University, Bangladesh. 
LEE, S., MOURI, Y., MINODA, M., ONEDA, H. AND INOUYE, K. 2006. Comparison of the wild-type $\alpha$-amylase and its variant enzymes in Bacillus amyloliquefaciens in activity and thermal stability and insights into engineering the thermal stability of Bacillus $\alpha$-amylase . Journal of Biochemistry. 139(6): 1007-1015.

LOWRY, O.H., ROSEBROUGH, N.J., FAR, A.L. AND RANDAL, R.J. 1951. Protein measurement with the folin-phenol reagent. J. Biol. Chem. 193:265-275.

MAHADEVAN, A. AND SRIDHAR, R.1982. Methods in Physiological Plant Pathology. Sivakami Publication, Madras.

MALEK, M.A., CHOWDHURY, N., CHOWDHURY, N.A.,YOUSSOUF, Q.M. AND MOLLAH, R.A. 1987. Degradation of cellulosic substances by Cytophaga sp. Bangladesh. J. Microbiol. 4(1):1-6.

MANCHUR, M.A. AND ANWAR, M.N. 1998. Isolation of thermophilic microbes and screening for their cellulase activity, saccharification protein biomass production. Bangladesh J. Bot. 27 (1) :25-30.

MANDEL, S. M. AND REESE, E. T. 1957. Induction of cellulase in Trichoderma viridae as influenced by carbon sources and metals. $J$. Bacteriol. 73:269-278.

MANDEL, S. M., PARRISH, F.W. AND REESE, E.T. 1962. Sophorose as an inducer of cellulase in Trichoderma reesei. J. Bacteriol. 83: 400-408.

MANDEL S.M. AND WEBER, J. 1969. The production of cellulase. In Cellulase and their applications. Edited by R.F. Gould. Adv. Chem. Ser. 95. Am. Chem. Soc. Washigton, Dc. pp. 391-414.

MARTIN, G.M. AND EBERHART, B. 1966. Regulation of cellulose and cellobiose in Neurospora crassa. Biochem. Biophys. Res. Commun. 24:782-785.

MORTUZA, G. 1993. Studies on cellulolytic microorganism of soil under the Albizia procera benth. forest plantation M. Sc. Thesis. Department of Botany, Chittagong University, Bangladesh.

NISIZAWA. T., SUZUKI, H. AND NISIZAWA, K. 1972. Catabolic repression of cellulase formation in Trichoderma viridae. J. Biochem 71: 999-1007.

OKAMI, Y. AND HOTTA, K. 1988. Search and discovery of new antibiotics. In Actinomycetes in Biotechnology,Edited by M. Goodfellow, S. T. Williams \& M. Mordarski. London: Academic Press. pp. 37-67.

OZTURK, H. B., OKUBAYASHI, S. AND BECHTOLD, T. 2006. Splitting tendency of cellulosic fibers-Part 1. The effect of shear force on mechanical stability of swollen lyocell fibers. Cellulose 13(4):393-402. 
ISOLATION, IDENTIFICATION AND CHARACTERIZATION OF FOUR CELLULOLYTIC ACTINOMYCETES AND THEIR CELLULASES

RAHMAN, M.R. AND ANWAR, M.N. 1996. Isolation of thermophilic fungi and screening for their cellulase activity, saccharification, protein and biomass production. Bangladesh J. Microbiol. 132(1\&2):57-62.

REDDY, P.P. 1984. Bioconversion of wheat straw cellulosic substrates by molds under submerged and solid state fermentations. M.Sc. dissertation, Kuruk Ashetra University, Kurukastra.

SEMEDO, L.T.A.S., LINHARES, A.A., GOMES, R.C., MANFIO, G.P., ALVIANO, C.S., LINHARES, L.F. AND COELHO, R.R.R. 2001. Isolation and characterization of actinomycetes from Brazilian tropical soils. Microbiol Res. 155: 291-299.

SHAILENDRA, S., BAHADUR, J. AND AJIT, V. 1991. Production and localization of carboxy methyl cellulose, xylanase and $\beta$-glucosidase from Cellulomonas and Micrococcus sp. Appl. Microbiol. Biotechnol. 34:668670.

SHEWALE, J.G. AND SADANA, J.C. 1968. Cellulase production by basidiomycetes. Can. J. Microbiol. 24: 1204-1216.

SOMOGYI, N. 1944. A photometric adaptation of the Somogyi method for the determination of glucose. J. Biol. Chem. 153:375-380.

SHIBLI, M., MANCHUR, M.A. AND ANWAR, M.N. 2001. Isolation of cellulolytic microorganism and screening for their cellulase activity, saccharification, protein and biomass production. Chittagong Univ. J. Sci. 25(2): 31-36.

SHIBLI, M., MANCHUR, M.A. AND ANWAR, M.N. 2002. Enzymatic saccharification of cellulosic materials by two indigenous fungal isolates. Bangladesh J. Microbiol. 19:31-34.

TOKUDA, G. AND WATANABE, H. 2007. Hidden cellulases in termites: revision of an old hypothesis. Biology Letters 3 (3): 336-339.

UPDEGRAFF, D. M. 1969. Semimicro determination of cellulose in biological materials. Analytical Biochemistry. 32:420-424.

ZAKIR, S.M. 1994. Study of cellulolytic microorganisms for their cellulase saccharification and biomass production. M.Sc. Thesis. Department of Botany, Chittagong University, Bangladesh.

ZAMAN, M.N. 1990. Preliminary study of cellulolytic microorganisms for their cellulase and biomass production. M.Sc. Thesis. Department of Botany, Chittagong University, Bangladesh.

Manuscript received on 04.03.2012; Accepted on 07.07.2012

The Chittagong University Journal of Biological Sciences, Vol. $6(1$ \& 2). Page No. 